\title{
Insect growth regulatory activities from oils of camphor and clove against Spilosoma obliqua
}

\section{Priyanka Bhatt* Nitin Thodsare and R.P. Srivastava}

Bioactive Plant Natural Product Laboratory, Department of Entomology, College of Agriculture, Govind Ballabh Pant University of Agriculture \& Technology, Pantnagar -263145 (Uttarakhand), INDIA

*Coressponding author. E-mail: bhattpriyanka18j@gmail.com

Received: AUGUST 26, 2015; Revised received: May 25, 2016; Accepted: August 02, 2016

Abstract: The present study was conducted to evaluate the insecticidal and growth regulatory activities of clove oil, Syzygium aromaticum and camphor oil, Cinammomum camphora against Bihar hairy caterpillar, Spilosoma obliqua. The fourth instar larvae were subjected to topical application by microapplicator syringe with doses of 2.5, 2.0, 1.5, 1.0 and $0.5 \mu \mathrm{l} / \mathrm{larva}$. Camphor oil was most effective at 2.5, 2.0 and $1.5 \mu \mathrm{l}$ dose causing death of larvae ranging from $76-90 \%$. It showed a strong growth regulatory activity with no adult emergence at the highest concentration. Clove oil was effective in reducing adult moth population to $27 \%$ at highest dose of $2.5 \mu \mathrm{l}$. Only this dose could cause larval mortality of about $60 \%$. The study shows potential of these oils to be utilized as insecticides or antibiosis mechanism to suppress the population of $S$. obliqua.

Keywords: Botanicals, Camphor oil, Clove oil, Growth Regulatory Activity, Spilosoma obliqua

\section{INTRODUCTION}

The Bihar hairy caterpillar, Spilosoma obliqua is highly polyphagous pest feeding on almost all green vegetation. The major hosts include groundnut, sunflower, cashew, castor, cucurbits, mulberry, pigeon pea, other pulses, millets, etc.. The larvae are gregarious feeding on leaves and in severe infestation the whole crop is defoliated. For long time, the chemical pesticides have been the sole control measures which have given rise to many well-known and serious problems, including genetic resistance of pest species, toxic residues in stored products, increasing costs of application, hazards from handling, environmental pollution (Rembold, 1994). Bihar hairy caterpillar has shown certain level of behavioural resistance to different classes of insecticides and it is due to this reason the pest is difficult to control (Mondal et al., 2013). In this context, botanical pesticides such as plant essential oils exert a wide range of behavioural and physiological effects on colonization, development, growth, survival and multiplication of insects. Essential oils are effective as contact and fumigant insecticides to a majority of insect pests giving quick knock down action above $1 \%$ concentration. Mostly components of essential oils are lipophilic in nature, which acts like oviposition deterrents, feeding deterrents, repellents and toxins to a broad range of insect pests. Essential oils offer an alternative source of insect control agents because they contain a range of bioactive chemicals, most of which are selective and have little or no harmful effect on the environment and the non-target organ- isms (Arshad et al., 2014). This study was of great interest to investigate some alternative natural methods exploiting essential oils as substitutes for insecticides in the control of Spilosoma obliqua.

\section{MATERIALS AND METHODS}

The Dried flower buds of Syzygium aromaticum (clove) and leaves of Cinnamomum camphora (camphor) were obtained from Medicinal Plants Research and Development Centre (MRDC), G.B.Pant University of Agriculture \& Technology, Pantnagar Uttarakhand. The oil from flower buds and leaves were extracted by hydrodistillation method (Ray et al., 2008). The distilled oil was separated from water by funnel and stored in refrigerator for further use. Adults of test insects S.obliqua were collected from Norman E. Borlaug Crop Research Centre of GBPUAT, Pantnagar. Insects were transferred separately to glass jars having an inner lining of white paper. Cotton soaked in $10 \%$ sucrose solution kept in a small petri plate was put in the jar for adult feeding. The eggs so obtained were kept in plastic boxes and the neonate larvae were transferred to plastic tubs containing fresh and soft leaves of castor with the help of fine brush. Fresh food was supplied daily. Five doses of each of the oils 2.5 , $2.0,1.5,1.0$ and $0.5 \mu 1$ were topically applied to the thoracic region of cold immobilized individual fourth instar larvae by microapplicator syringe (Prajapati et al., 1998, Pavela, 2005., Tandon et al., 2008). Three replications were maintained. Control was untreated. The treated larvae were transferred to separate plastic boxes containing untreated castor leaves as food. The 
data on mortality was recorded at days after exposure (DAE). Moribund larvae were counted as dead. The other observations were recorded on the following parameters:larval weight (g), larval period (d), pupal period (d), pupal weight $(\mathrm{g})$, adult emergence (\%) and terminal larval mortality $(\%)$. The growth and development parameters were analysed using one way ANOVA. Significant differences between treatments were determined using Duncan multiple range test $(\mathrm{P} \leq 0.05)$.

\section{RESULTS AND DISCUSSION}

Camphor oil C. camphora was most effective in its insect growth regulatory activity against Bihar hairy caterpillar. Mean larval weight (Table 1) was significantly reduced at 2.5, 2.0 and 1.5 $\mu 1 /$ larva dose with values being $0.07,0.11$ and $0.049 \mathrm{~g}$ as compared to untreated control $(0.289 \mathrm{~g})$. Larval mortality was highest $(66.66 \%)$ at $2.5 \mu 1$ dose. Due to the application of oil at thoracic region of the larvae the larval hairs were lost, the skin turned black, larvae failed to moult and finally died at doses above $1.5 \mu \mathrm{l}$. Larval period and pupal period were at par to control. The terminal larval mortality (90\%) which indicated death of larvae before reaching pupation was highest at $2.5 \mu 1$ (Table 2). The oil reduced pupation per cent at 2.5, 2.0 and 1.5 $\mu \mathrm{l} /$ larva, to $10.23,23.33$ and $23.33 \%$ respectively. The same response was reported during adult emergence .None of the moths could emerge at $2.5 \mu 1$ dose. Control recorded $96.66 \%$ adults while only $13.33 \%$ moths emerged at $2.0 \mu 1$ dose. The toxicity in camphor

Table 1. Effect of camphor oil on growth of fourth instar larvae of Spilosoma oblique.

\begin{tabular}{ccccc}
\hline Plant oil & $\begin{array}{c}\text { Conc. } \\
(\boldsymbol{\mu l})\end{array}$ & $\begin{array}{c}\text { Mean weight /larva } \\
\text { 2 DAE }(\mathbf{g})\end{array}$ & $\begin{array}{c}\text { Mean weight gain/ } \\
\text { larva } \\
\text { 2 DAE }(\mathbf{g})\end{array}$ & $\begin{array}{c}\text { Larval mortality } \\
(\boldsymbol{\%})\end{array}$ \\
\hline Cinnamomum camphora & 2.5 & $0.388 \pm 0.10^{\mathrm{a}}$ & $0.073 \pm 0.10^{\mathrm{a}}$ & $66.66 \pm 23.09^{\mathrm{c}}$ \\
& 2.0 & $0.499 \pm 0.02^{\mathrm{ab}}$ & $0.119 \pm 0.02^{\mathrm{ab}}$ & $33.33 \pm 20.81^{\mathrm{b}}$ \\
& 1.5 & $0.429 \pm 0.05^{\mathrm{a}}$ & $0.049 \pm 0.05^{\mathrm{a}}$ & $26.66 \pm 15.27^{\mathrm{ab}}$ \\
& 1.0 & $0.569 \pm 0.08^{\mathrm{bc}}$ & $0.189 \pm 0.08^{\mathrm{bc}}$ & $0.00 \pm 0.00^{\mathrm{a}}$ \\
Control (Untreated) & 0.5 & $0.653 \pm 0.05^{\mathrm{c}}$ & $0.273 \pm 0.05^{\mathrm{d}}$ & $0.00 \pm 0.00^{\mathrm{a}}$ \\
\hline
\end{tabular}

Within column, means \pm SD followed by the same letter do not differ significantly using DMRT, $\mathrm{P} \leq 0.05, \mathrm{DAE}=\mathrm{Days}$ after exposure

Table 2. Effect of camphor oil on development of fourth instar larvae of Spilosoma obliqua

\begin{tabular}{lccccccc}
\hline Plant oil & $\begin{array}{c}\text { Conc. } \\
(\boldsymbol{\mu l})\end{array}$ & $\begin{array}{c}\text { Larval pe- } \\
\text { riod } \\
(\mathbf{d})\end{array}$ & $\begin{array}{c}\text { Terminal } \\
\text { larval mor- } \\
\text { tality } \\
(\boldsymbol{\%})\end{array}$ & $\begin{array}{c}\text { Pupal pe- } \\
\text { riod } \\
(\mathbf{d})\end{array}$ & $\begin{array}{c}\text { Mean pupal } \\
\text { weight } \\
(\mathbf{g})\end{array}$ & $\begin{array}{c}\text { Pupation } \\
(\boldsymbol{\%})\end{array}$ & $\begin{array}{c}\text { Adult emer- } \\
\text { gence } \\
(\boldsymbol{\%})\end{array}$ \\
\hline $\begin{array}{l}\text { Cinnamo- } \\
\text { mum cam- }\end{array}$ & 2.5 & $21.00 \pm 7.47^{\mathrm{ab}}$ & $90.00 \pm 10.00^{\mathrm{c}}$ & $10.66 \pm 0.57^{\mathrm{a}}$ & $0.257 \pm 0.23^{\mathrm{a}}$ & $10.00 \pm 10.00^{\mathrm{a}}$ & $0.00 \pm 0.00^{\mathrm{a}}$ \\
phora & 2.0 & $21.17 \pm 9.25^{\mathrm{b}}$ & $76.66 \pm 15.27^{\mathrm{c}}$ & $10.77 \pm 0.38^{\mathrm{b}}$ & $0.456 \pm 0.06^{\mathrm{a}}$ & $23.33 \pm 15.27^{\mathrm{a}}$ & $13.33 \pm 11.54^{\mathrm{a}}$ \\
& 1.5 & $21.19 \pm 10.07^{\mathrm{b}}$ & $76.66 \pm 11.54^{\mathrm{c}}$ & $11.00 \pm 0.00^{\mathrm{b}}$ & $0.207 \pm 0.19^{\mathrm{a}}$ & $23.33 \pm 11.54^{\mathrm{a}}$ & $23.33 \pm 32.14^{\mathrm{ab}}$ \\
& 1.0 & $20.73 \pm 10.40^{\mathrm{a}}$ & $26.66 \pm 15.27^{\mathrm{b}}$ & $11.00 \pm 0.00^{\mathrm{a}}$ & $0.390 \pm 0.05^{\mathrm{b}}$ & $73.33 \pm 15.27^{\mathrm{b}}$ & $53.33 \pm 23.09^{\mathrm{bc}}$ \\
& 0.5 & $20.93 \pm 10.59^{\mathrm{ab}}$ & $10.00 \pm 10.00^{\mathrm{ab}}$ & $10.66 \pm 0.577$ & $0.390 \pm 0.035^{\mathrm{a}}$ & $90.00 \pm 10.00^{\mathrm{bc}}$ & $60.00 \pm 20.00^{\mathrm{c}}$ \\
\hline Control & - & $21.00 \pm 10.36^{\mathrm{ab}}$ & $0.00 \pm 0.00^{\mathrm{a}}$ & $10.00 \pm 0.00^{\mathrm{a}}$ & $0.386 \pm 0.033^{\mathrm{a}}$ & $100 \pm 0.00^{\mathrm{bc}}$ & $96.66 \pm 5.77^{\mathrm{d}}$ \\
(Untreated) & & & & & & & \\
\hline
\end{tabular}

Within column, means \pm SD followed by the same letter do not differ significantly using DMRT, $\mathrm{P} \leq 0.05$.

Table3. Effect of clove oil on growth of fourth instar larvae of Spilosoma obliqua

\begin{tabular}{|c|c|c|c|c|}
\hline Plant oil & $\begin{array}{c}\text { Conc. } \\
(\mu \mathrm{l})\end{array}$ & $\begin{array}{l}\text { Mean weight /larva } \\
2 \text { DAE (g) }\end{array}$ & $\begin{array}{l}\text { Mean weight (g) gain/ } \\
\text { larva } 2 \text { DAE }\end{array}$ & $\begin{array}{c}\text { Larval mortality } \\
(\%)\end{array}$ \\
\hline \multirow[t]{5}{*}{ Syzygium aromaticum } & 2.5 & $0.608 \pm 0.10^{\mathrm{a}}$ & $0.340 \pm 0.10^{\mathrm{a}}$ & $60.00 \pm 10^{c}$ \\
\hline & 2.0 & $0.640 \pm 0.03^{\mathrm{a}}$ & $0.357 \pm 0.03^{\mathrm{a}}$ & $23.33 \pm 5.77^{\mathrm{b}}$ \\
\hline & 1.5 & $0.625 \pm 0.03^{\mathrm{a}}$ & $0.372 \pm 0.03^{\mathrm{a}}$ & $16.66 \pm 15.27^{\mathrm{b}}$ \\
\hline & 1.0 & $0.709 \pm 0.01^{\mathrm{ab}}$ & $0.441 \pm 0.01^{\mathrm{ab}}$ & $0.00 \pm 0.00^{\mathrm{a}}$ \\
\hline & 0.5 & $0.711 \pm 0.001^{\mathrm{ab}}$ & $0.443 \pm 0.001^{\mathrm{ab}}$ & $0.00 \pm 0.00^{\mathrm{a}}$ \\
\hline Control (Untreated) & - & $0.745 \pm 0.05^{\mathrm{b}}$ & $0.477 \pm 0.05^{\mathrm{b}}$ & $0.00 \pm 0.00^{\mathrm{a}}$ \\
\hline
\end{tabular}

Within column, means \pm SD followed by the same letter do not differ significantly using DMRT, $\mathrm{P} \leq 0.05$.., DAE $=$ Days after exposure 
Priyanka Bhatt et al. / J. Appl. \& Nat. Sci. 8 (3): 1434 - 1437 (2016)

Table 4. Effect of clove oil on development of fourth instar larvae of Spilosoma oblique.

\begin{tabular}{|c|c|c|c|c|c|c|c|}
\hline Plant oil & $\begin{array}{c}\text { Conc. } \\
(\mu \mathrm{l})\end{array}$ & $\begin{array}{l}\text { Larval pe- } \\
\text { riod } \\
\text { (d) }\end{array}$ & $\begin{array}{c}\text { Terminal larval } \\
\text { mortality } \\
(\%)\end{array}$ & $\begin{array}{l}\text { Pupal pe- } \\
\text { riod } \\
\text { (d) }\end{array}$ & $\begin{array}{l}\text { Mean pupal } \\
\text { weight } \\
\text { (g) }\end{array}$ & $\begin{array}{l}\text { Pupa- } \\
\text { tion }(\%)\end{array}$ & $\begin{array}{l}\text { Adult emergence } \\
\text { [On the basis of } \\
\text { pupation] }(\%)\end{array}$ \\
\hline \multirow{5}{*}{$\begin{array}{l}\text { Syzyigium } \\
\text { aromati- } \\
\text { cum }\end{array}$} & 2.5 & $20.00 \pm 0.00^{\mathrm{a}}$ & $70.00 \pm 0.00^{\mathrm{c}}$ & $11.55 \pm 0.50^{\mathrm{a}}$ & $0.367 \pm 0.02^{\mathrm{a}}$ & $\begin{array}{c}26.66 \pm 15 \\
27^{\mathrm{a}}\end{array}$ & $26.66 \pm 15.27^{\mathrm{a}}$ \\
\hline & 2.0 & $20.47 \pm 0.13^{\mathrm{a}}$ & $46.66 \pm 20.81^{\mathrm{b}}$ & $11.52 \pm 0.50^{\mathrm{a}}$ & $0.393 \pm 0.12^{\mathrm{a}}$ & $\begin{array}{c}53.33 \pm 20 \\
.81^{\mathrm{b}}\end{array}$ & $36.66 \pm 30.55^{\mathrm{ab}}$ \\
\hline & 1.5 & $20.58 \pm 0.52^{\mathrm{a}}$ & $36.66 \pm 5.77^{\mathrm{b}}$ & $12.80 \pm 0.72^{\mathrm{b}}$ & $0.476 \pm 0.01^{\mathrm{a}}$ & $\begin{array}{c}63.33 \pm 5 \\
77^{\mathrm{b}}\end{array}$ & $50.00 \pm 26.45^{\mathrm{ab}}$ \\
\hline & 1.0 & $20.75 \pm 0.05^{\mathrm{a}}$ & $10.00 \pm 10.00^{\mathrm{a}}$ & $12.91 \pm 0.97^{\mathrm{b}}$ & $0.445 \pm 0.02^{\mathrm{a}}$ & $\begin{array}{c}90.00 \pm 10 \\
.00^{\mathrm{c}}\end{array}$ & $66.66 \pm 15.27^{\mathrm{bc}}$ \\
\hline & 0.5 & $20.63 \pm 0.55^{\mathrm{a}}$ & $10.00 \pm 10.00^{\mathrm{a}}$ & $12.77 \pm 0.58^{\mathrm{b}}$ & $0.519 \pm 0.16^{\mathrm{a}}$ & $\begin{array}{c}90.00 \pm 10 \\
.00^{c}\end{array}$ & $86.66 \pm 5.77^{\mathrm{c}}$ \\
\hline $\begin{array}{l}\text { Control } \\
\text { (Untreated) }\end{array}$ & - & $20.13 \pm 0.75^{\mathrm{a}}$ & $0.00 \pm 0.00^{\mathrm{a}}$ & $12.63 \pm 0.25^{\mathrm{ab}}$ & $0.440 \pm 0.01^{\mathrm{a}}$ & $\begin{array}{c}100.00 \pm 0 \\
.00^{\mathrm{c}}\end{array}$ & $100.00 \pm 0.00^{c}$ \\
\hline
\end{tabular}

Within column, means \pm SD followed by the same letter do not differ significantly using DMRT, $\mathrm{P} \leq 0.05$.

oil may be due to the presence of fenchone $(34.82 \%)$, camphene $(23.77 \%), \alpha$ - thujene $(17.45 \%)$, L-limolene $(7.54 \%)$ and cis-p-methane $(5.81 \%)$ as reported by Srivastava et al (2008). Cinnamaldehyde, eugenol, cinnamyl acetate and essential oils from different $\mathrm{Cin}$ namomum species are effective mosquito larvicides ( Huang et al., 1998, Cheng et al., 2004). The toxicity of clove $S$. aromaticum oil on growth and development parameters is depicted in tables 3 and 4, the lower doses were at par to control in terms of reduction in weight gain. Per cent reduction in weight gain was highest $(28.73 \%)$ at $2.5 \mu \mathrm{l}$ and lowest $(7.13 \%)$ at $0.5 \mu 1$ in comparison to control (mean larval weight gain $0.47 \mathrm{~g}$ ). The highest dose viz. $2.5 \mu \mathrm{l}$ was most effective causing more than average larval $(60 \%)$ and terminal larval $(70 \%)$ mortality. There was no significant effect on larval and pupal durations. Low pupation per cent was noticed at $2.5(26.66 \%), 2.0(53.33 \%)$ and $1.5 \mu 1$ $(63.33 \%)$. The oil reduced adult moth population by $26.66,36.66$ and $50 \%$ at $2.5,2.0$ and $1.5 \mu 1$ doses respectively. Clove bud oil has biological activities, such as antibacterial, antifungal, insecticidal and antioxidant activities and are used traditionally as flavoring agents and antimicrobial material in food (Lee \& Shibamoto, 2001., Huang \& Ho, 2002). Several compounds from S.aromaticum (namely5,7-dihydroxy-2-methylchromone8-C-D-glucopyranoside, biflorin, kaempferol, rhamnocitrin, myricetin, gallic acid, ellagic acid and oleanolic acid) have been found to possess growth inhibitory activity against oral pathogens (Cai \& Wu, 1996). In our study C. camphora and S. aromaticum oils were effective in controlling insect development at doses above $1.5 \mu \mathrm{l}$. These oils could be effectively used in pest management programmes as potential insecticides, though we could not find enough research findings on the toxicity of these oils to S. obliqua. Workers have reported toxicity of these essential oils against other moths, for example C.zelanicum has been reported to be toxic to the larvae of Indian meal moth Plodia interpunctella (Rafiei et al, 2009a., Rafiei et al., 2009b). C.camphora oil has also been reported to be toxic to Sitotroga cerealella and Ephestia kuehniella. ( Allahvaisi et al., 2011).S. aromaticum essential oil exhibited inhibition of $\mathrm{F} 1$ progeny from 61.08 to $91.52 \%$ against Sitophilus oryzae (Sharma \& Meshram, 2006). Clove oil has also been reported to show contact and fumigant toxicities against adults of Musca domestica (Pavela, 2008), ovicidal effect against Tribolium castaneum (Mandal \& Khalequzzaman, 2009), repellent activity against Blattella germanica, Periplaneta americana and $P$. fuliginosa (Yoon et al, 2009), larvicidal against both pyrethroid-susceptible and resistant Ades aegypti (Sutthanont et al., 2010), repellency to adults and larvae and ovicidal, larvicidal and adulticidal against Tribolium castaneum (Ajayi \& Olonisakin, 2011), toxicity against the workers of the Odontotermes obesus termite (Gupta et al., 2011) S.aromaticun oil have been found to be repellent to fifth instar larvae of Sitotraga cerealella and Ephestia kuehniella and strong feeding deterrent activity have been reported against Trichoplusia ni (Akhtar et al., 2012).The study shows the oils of C.camphora and S.aromaticum, if used at a higher concentration could serve as effective insecticides and insect growth regulators impairing normal development of agriculturally important insect defoliators.

\section{Conclusion}

It is clearly evident that oils from camphor and clove were highly potent in their insecticidal activity against Bihar hairy caterpillar. The oils showed IGR activity above $1.5 \mu 1$ dose/larva. Camphor oil was more effective at $2.0 \& 2.5 \mu \mathrm{l}$. causing about 76 and $90 \%$ terminal larval mortality respectively with only $10 \%$ of conversion of larvae into pupae at the highest dose of $2.5 \mu \mathrm{l} /$ larva. No adults were formed at this dose of camphor oil. As compared to camphor oil, clove oil was less toxic causing about $70 \%$ terminal larval mortality at the highest dose of $2.5 \mu 1 /$ larva allowing $27 \%$ of adult emergence. Utilization of camphor and clove oil in pest management programmes will reduce reliance on synthetic pesticides as well as hamper build up of resistance in insect popula- 
tions. The use of oils is also compatible with integrated pest management tactics for sustainable agriculture with minimum risk to the ecosystem.

\section{ACKNOWLEDGEMENTS}

The authors are thankful to the Department of Entomology, G.B.Pant University of Agriculture \& Technology, Pantnagar, Uttarakhand, for providing necessary facilities to conduct research.

\section{REFERENCES}

Ajayi FA, Olonisakin A.(2011). Bioactivity of three essential oils extracted from edible seeds on the rust-red flour beetle, Tribolium castaneum (Herbst.) infesting pearl millet. Trakia Journal of Sciences, 9(1):28-36.

Akhtar Y, Pages E, Stevens A, Bradbur R, Da C A G, Isman M. B. (2012). Effect of chemical complexity of essential oils on feeding deterrence in larvae of the cabbage looper. Physiology Entomology, 37:81-91.

Allahvaisi S, Maroufpoor M, Abdolmaleki A, Hoceini S A, Ghasemzadeh.(2011). The effect of plant oils for reducing contamination of stored packaged- foodstuffs. Journal of Plant. Protection. Reserarch 2011; 51:82-86.

Arshad Z, Hanif A M, Qadra R W K, Khan M M.(2014). Role of essential oils in plant diseases protection A review. International Journal of Chemical and Biochemical Sciences, 6:11-17.

Cai L, Wu, C D. (1996).Compounds from Syzygium aromaticum possessing growth inhibitory activity against oral pathogens. Journal of Natural Products, 59:987-990.

Cheng S S, Liu J Y, Tsai K H, Chen W J, Chang, S T. (2004) .Chemical composition and mosquito larvicidal activity of essential oils from leaves of different Cinnomomum osmophloeum provenances. Journal of Agricultural Food Chemistry, 52: 4395- 4400.

Gupta A, Sharma S, Naik S N.(2011). Biopesticidal value of selected essential oils against pathogenic fungus, termites, and nematodes. International Biodeterioration Biodegradation, 65:703-707.

Huang Y, Ho SH. (2002). Insecticidal properties of eugenol, isoeugenol and methyleugenol and their effects on nutrition of Sitophilus zeamais Motsch (Coleoptera: Curculionidae) and Tribolium castaneum (Herbst) (Coleoptera: Tenebrionidae). Journal of Stored Products Research, 38(5):403-412.

Huang Y, Ho S H, Kini R M. (1998). Bioactivities of safrole and isosafrole on Sitophilus zeamais (Coleoptera: Curculionidae) and Tribolium castaneum (Coleoptera: Tenebrionidae). Journal of Economic Entomology, 92: 676-683.

Lee K, Shibamoto, T. Antioxidant property of aroma extract isolated from clove buds [Syzygium aromaticum (L.) Merr. Perry]. Food Chemistry 2001; 74:443-448.

Mondal, D, Bhowmik P, Barel K.(2013).Evaluation of insecticides for the management of Bihar hairy caterpillar, Spilosoma obliqua Walk. (Lepidoptera: Arctiidae) in black gram (Vigna mungo L.).The Bioscan, 8(2): 429-431.

Mandal M, Khalequzzaman, M.(2009).Ovicidal activity of essential oils against red flour beetle, Tribolium castaneum (Herbst) (Coleoptera: Tenebrionidae). Journal of Biological. Sciences, 17:57-62.

Pavela R.(2005).Insecticidal activity of some essential oils against larvae of Spodoptera littoralis. Fitoterapia, 76:691-696.

Pavela R.(2008). Insecticidal properties of several essential oils on the house fly (Musca domestica L.). Phytotherapy Research, 22:274-78.

Prajapati V, Tripathi A K, Jain D C, Sharma S, Khanuja SPS.(1998). Senstivity of Spilarctia obliqua to root extracts of Cantharanthus roseus. Phytotherapy Research, 12:270-274.

Rafiei-Karahroodi Z, Moharamipour S, Rahbarpour A. (2009a). Investigated repellency effect of some essential oils of 17 native medicinal plants on adults Plodia interpunctella. American.

Eurasian Journal of. Sustainable Agriculture, 3:181-184.

Rafiei-Karahroodi Z, Moharamipour S, Farazmand H, Karimzadeh- Esfahani, J.(2009b). Effect of eighteen plant essential oils on nutritional indices of larvae Plodia interpunctella Hubner (Lep., Pyralidae). Journal of Entomological. Research,1: 209-219.

Ray D P, Dureja P, Walia S(2008) .Evaluation of marigold (Tagetes erecta L.) flower essential oil for antifeedant activity against Spodoptera litura F. Pesticide Research Journal , 20(1):10-12.

Rembold H. (1994) .Secondary plant compounds in insect control with special reference to Azadirachtin. Advances in Invertebrate Reproduction, 3: 481- 491.

Sharma K, Meshram, N M.(2006). Bioactive of essential oils from Acorus calamus Linnaeus and Syzygium aromaticum Linnaeus against Sitophilus oryzae (Linnaeus) in stored wheat. Biopesticides International, 2(2):144-52.

Srivastava B P, Singh R, Shukla N K Dubey. (2008). A novel combination of the essential oils of Cinnamomum camphora and Alpinia galanga in checking aflatoxin B1 production by a toxigenic strain of Aspergillus flavus. World Journal of Microbial Biotechnology, 24: 693-697.

Sutthanont N, Choochote W, Tuetun B, Junkum A, Jitpakdi A, Chaithong U, Riyong D, Pitasawat B.(2010). Chemical composition and larvicidal activity of edible plant-derived essential oils against the pyrethroidsusceptible and -resistant strains of Aedes aegypti (Diptera: Culicidae). Journal of Vector Ecology, 35 (1):106-115.

Tandon S, Mittal A, Pant A K.(2008). Insect growth regulatory activity of Vitex trifolia and Vitex agnus-castus essential oils against Spilosoma obliqua. Fitoterapia, 79 (4): 283-286.

Yoon C, Kang S H, Yang J O, Noh D J, Indiragandhi P, Kim G H (2009). Repellent activity of citrus oils against the cockroaches Blattella germanica, Periplaneta americana and P. fuliginosa. Journal of Pesticide Science, 34(2):77-88. 